\title{
Financial Statements Fraud Detection: Analysis of Beneish and Roxas Models Applicability (Russian Approach)
}

\author{
${ }^{\otimes}$ Elena Vetoshkina, ${ }^{2}$ Polina Cherepanova, ${ }^{3}$ Natalya Semenikhina,,${ }^{4}$ Ruslan Tukhvatullin \\ 1,3,4 Department of Accounting, Analysis and Audit, Institute of Management, Economics and Finance, Kazan \\ Federal University \\ pulya_1978@mail.ru \\ nt.sem@mail.ru \\ rustu@bk.ru \\ ${ }^{2}$ Institute of Management, Economics and Finance, Kazan Federal University, Kazan, Russian Federation, \\ polinaric1@gmail.com
}

\section{Received: 21st August 2020, Accepted: 14th September 2020, Published: 31st October 2020}

\begin{abstract}
It is well known that there are many reasons for economic entities to distort their financial statements deliberately. It is a general practice, that reporting becomes the subject for management's manipulation. For example, top staff seeks to reduce the tax base by undercharging the profits in accounting (financial) statements. It expects to attract the maximum number of investors as their positive expectations have a beneficial effect on the growth of the market value of shares and the strengthening of the position of the economic entity in the market. Illegal actions misinform the users and mislead them. Distorted reporting also has a negative impact on management decisions, and it jeopardizes the existence of the company. As evidenced in practice the economic analysis is not always able to reveal the fact of fraud immediately. Checking the accounting (financial) statements for distortions is the most important stage in the process of audit. This method is very useful as a tool of reducing the risk of undetected distortions.
\end{abstract}

\section{Keywords}

Fraud; Fraudulent; M-Score Index; Audit; Analysis

\section{Introduction}

In their work, auditors use various mathematical methods to identify illegal acts, which may also be based on the use of discriminant and regression types of analyses. They also use the techniques of economic analysis. Such methods are justified by the requirements of International Auditing Standard 520 "Analytical Procedures".

One frequently encountered tool to test reporting for distortions is the method developed by Professor Messod D. Beneish in 1999. The methodology was the result of the analysis of the statements of 74 companies that had manipulated data in the statements, and 2,332 companies with unfalsified reporting. The model used financial reporting data to construct variables that could reflect the effects of the misstatements. As a result, an aggregate index (M-score) was obtained to assess the risk of distortion of the accounting (financial) statements in the company. The above-mentioned model uses eight indicators, which are indices determined based on the accounting (financial) statements of companies. This model allows identifying certain discrepancies in the data presented in the financial statements of companies, and non-standard fluctuations in the presented financial indicators, as well as their relationship. If indices exceed the boundary value set by Beneish $(-2.22)$, it indicates distortions in financial statements.

We will test the degree of distortion in the financial statements of the company under study based on the conclusions made within the research. The company belongs to the metal collection and processing market.

The analysis of academic works showed that this problem has already been raised by many scholars in Russia and 
around the world $[1 ; 7 ; 8 ; 9 ; 11]$.

\section{Method}

The model was based on financial reporting data. The variables that could reflect the effects of the misstatements were constructed.

As a result, an aggregate index (M-score) was obtained to assess the risk of distortion of the accounting (financial) statements in the company. The M-score is calculated according to the following formula:

M-score $=4,84+0,92 \times \mathrm{DSRI}+0,528 \times \mathrm{GMI}+0,404 \times \mathrm{AQI}+0,892 \times \mathrm{SGI}+0,115 \times \mathrm{DEPI}-0,172 \times \mathrm{SGAI}+4,679 \times$

TATA $-0,327 \times$ LVGI

where DSRI is days' sales in receivables index;

GMI is gross margin index;

$\mathrm{AQI}$ is asset quality index;

SGI is sales growth index;

DEPI is depreciation index;

SGAI is sales, general, and administrative expenses index;

TATA is total accruals to total assets;

LVGI is leverage index.

Each M-score element was found based on the balance sheet data and the statement of financial results to detect the presence of data manipulation (Table 1).

Table 1: Map of Regulatory Deviations of Financial Indicators

\begin{tabular}{|c|c|c|}
\hline Indicator & Designation & Formula \\
\hline $\begin{array}{l}\text { Days' sales in } \\
\text { receivables index }\end{array}$ & DSRI & (Net Receivablest / Salest) / (Net Receivablest-1 / Salest-1) \\
\hline Gross margin index & GMI & [(Salest-1 - COGSt-1) / Salest-1] / [(Salest - COGSt $) /$ Salest $]$ \\
\hline Asset quality index & AQI & $\begin{array}{l}{[1-(\text { Current Assetst }+ \text { PP\&Et }+ \text { Securitiest }) / \text { Total Assetst }] /[1} \\
((\text { Current Assetst-1 }+ \text { PP\&Et- } 1+\text { Securitiest- } 1) / \text { Total Assetst- } 1)]\end{array}$ \\
\hline Sales growth index & SGI & Salest / Salest-1 \\
\hline Depreciation index & DEPI & $\begin{array}{l}\text { (Depreciationt-1/ (PP\&Et-1 + Depreciationt-1)) / (Depreciationt } \\
(\text { PP\&Et }+ \text { Depreciationt }))\end{array}$ \\
\hline $\begin{array}{l}\text { Sales, general, and } \\
\text { administrative } \\
\text { expenses index }\end{array}$ & SGAI & (SG\&A Expenset / Salest) / (SG\&A Expenset-1 / Salest-1) \\
\hline Leverage index & LVGI & $\begin{array}{l}{[(\text { Current Liabilitiest }+ \text { Total Long Term Debtt }) / \text { Total Assetst }] /} \\
{[(\text { Current Liabilitiest-1 + Total Long Term Debtt- }) / \text { Total }} \\
\text { Assetst-1 }]\end{array}$ \\
\hline $\begin{array}{l}\text { Total accruals to total } \\
\text { assets }\end{array}$ & TATA & $\begin{array}{l}\text { (Income from Continuing Operationst - Cash Flows from } \\
\text { Operationst) / Total Assetst }\end{array}$ \\
\hline
\end{tabular}

Besides, Beneish determined the normative values of financial indicators. Their forward deflections indicated the presence of distortions in the accounting (financial) statements (Table 2). 
Table 2: Boundary Values of Indicators in the Beneish Model

\begin{tabular}{|l|l|l|l|l|l|l|l|l|}
\hline Indicator & DSRI & GMI & AQI & SGI & DEPI & SGAI & LVGI & TATA \\
\hline Value & 1,031 & 1,014 & 1,039 & 1,134 & 1,000 & 1,000 & 1,000 & 0,018 \\
\hline
\end{tabular}

The M-score value for economic entities whose reporting is not the subject of distortion should not exceed -2.22. The deviations prove distortions in the accounting (financial) statements. The presence of deviations in two or more indicators, with a normal value of M-score, may also confirm the fact of reporting distortion.

Beneish's research was continued by the scholar, Maria L. Roxas. She studied and tested the financial statements of 93 American companies in 1999-2008. Based on the results of the analysis, she proposed an alternative five-factor model of financial indicators. The index of commercial and managerial expenses, the coefficient of financial dependence and accrual to assets were excluded from the model due to their insignificant role:

M-score $=-6,065+0,823 \times \mathrm{DSRI}+0,906 \times \mathrm{GMI}+0,593 \times \mathrm{AQI}+0,717 \times \mathrm{SGI}+0,107 \times \mathrm{DEPI}$

where DSRI is days' sales in receivables index;

GMI is gross margin index;

$\mathrm{AQI}$ is asset quality index;

SGI is sales growth index;

DEPI is depreciation index.

If the calculated $\mathrm{M}$-score exceeds the standard value of -2.76 , the accounting (financial) statements are distorted.

It should be noted that Russian scholars N.V. Feruleva and M.A. Stefan propose to exclude two factors from the above-mentioned model. They are the depreciation index (DEPI) and the working capital change (TATA). This exclusion is explained by the specificity of information disclosure in the accounting (financial) statements: the information used to calculate the excluded indicators is not available in the accounting (financial) statements of Russian companies.

In our opinion, these exclusions are efficient as these factors do not affect the quality of the analysis. In practice, no cases of misrepresentation in accrued depreciation were identified. The majority of Russian companies use the linear depreciation method, the correct use of which is easy to double-check.

In this regard, N.V. Feruleva and M.A. Stefan recalculated the boundary values of the aggregated M-score indices according to Beneish and Roxas models (Table 3).

Table 3: Boundary Values of the Aggregated M-score Index for American and Russian Companies

\begin{tabular}{|l|c|c|c|c|}
\hline & \multicolumn{2}{|c|}{ Beneish Model } & \multicolumn{2}{c|}{ Roxas Model } \\
\hline & $\begin{array}{c}\text { For American } \\
\text { companies }\end{array}$ & $\begin{array}{c}\text { For Russian } \\
\text { companies }\end{array}$ & $\begin{array}{c}\text { For American } \\
\text { companies }\end{array}$ & $\begin{array}{c}\text { For Russian } \\
\text { companies }\end{array}$ \\
\hline Value M-score & $-2,424$ & $-1,802$ & $-2,965$ & $-2,146$ \\
\hline
\end{tabular}

The higher the financial indicators of the standart value are, the higher the risk of reporting distortion is (Table 4).

Thus, the standart values of financial indicators for Russian companies are higher than for American companies.

Table 4: Standard Values for Beneish and Roxas Models for Russian and American Companies

\begin{tabular}{|l|l|l|l|l|l|l|}
\hline \multirow{2}{*}{ Standart value } & \multicolumn{6}{|l|}{ Value } \\
\cline { 2 - 8 } & DSRI & GMI & AQI & SGI & SGAI & LVGI \\
\hline for Russian companies & 1,408 & 1,260 & 1,186 & 1,280 & 1,025 & 1,119 \\
\hline for American companies & 1,031 & 1,014 & 1,039 & 1,134 & 1 & 1 \\
\hline
\end{tabular}

This type of testing is easy to use. Its advantage is that it does not need complicated mathematical calculations and the use of special software. Thus, the process of testing data to detect manipulations becomes quicker and easier. We recommend this method to be used not only in audit practice but also before conducting a comprehensive economic 
analysis of an economic entity to identify the quality of the reporting information planned to be used in future analyses.

To compare Russian and American approaches to assessing distortion, we tested the financial statements of 15 Russian companies belonging to the ferrous and non-ferrous metal industry (collection, processing of ferrous and non-ferrous metals, and scrap). The calculation results are presented in Tables 5 and 6 .

Table 5: M-score Calculations for Beneish and Roxas Models

\begin{tabular}{|c|c|c|c|c|c|c|c|c|}
\hline \multirow[b]{2}{*}{ Company } & \multicolumn{8}{|c|}{ Indices } \\
\hline & $\begin{array}{l}\vec{n} \\
\tilde{n}\end{array}$ & $\sum_{0}$ & $\underset{<}{\sigma}$ & ত্ & 鹿 & $\stackrel{\Xi}{3}$ & 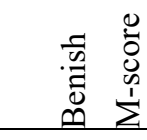 & 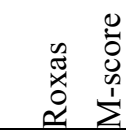 \\
\hline JSC "Uralelektromed" & 0,998 & 0,693 & 0,992 & 1,110 & 1,003 & 1,175 & $-2,719$ & $-3,229$ \\
\hline OJSC "Pskovvtormet" & 0,702 & 1,000 & 1,285 & 0,806 & 1,209 & 0,635 & $-2,841$ & $-3,239$ \\
\hline $\begin{array}{l}\text { PJSC "Nadezhdinski } \\
\text { Metallurgical Plant" }\end{array}$ & 1,159 & 1,135 & 0,534 & 1,053 & 0,948 & 1,206 & $-2,574$ & $-3,009$ \\
\hline $\begin{array}{l}\text { PJSC "Ashinski } \\
\text { Metallurgic Plant" }\end{array}$ & 0,628 & 1,388 & 0,839 & 1,085 & 1,059 & 0,916 & $-2,701$ & $-3,013$ \\
\hline PJSC "Ruspolymet" & 1,483 & 1,174 & 0,851 & 0,930 & 1,087 & 1,164 & $-2,247$ & $-2,607$ \\
\hline $\begin{array}{l}\text { JSC “Kamensk-Uralsky } \\
\text { Non-Ferrous Metal } \\
\text { Working Plant" }\end{array}$ & 0,854 & 1,032 & 0,627 & 0,996 & 1,193 & 0,997 & $-2,896$ & $-3,339$ \\
\hline OJSC "Susumanzoloto" & 1,133 & 1,051 & 0,787 & 1,244 & 0,923 & 0,839 & $-2,245$ & $-2,819$ \\
\hline LLC "Pravourmiyskoye" & 0,468 & 0,977 & 1,180 & 1,578 & 0,923 & 0,982 & $-2,487$ & $-2,962$ \\
\hline PJSC MMC “Nornickel” & 0,672 & 1,196 & 1,342 & 1,049 & 1,099 & 0,971 & $-2,616$ & $-2,879$ \\
\hline PAO Severstal & 0,636 & 0,941 & 1,251 & 1,095 & 0,992 & 0,904 & $-2,740$ & $-3,160$ \\
\hline $\begin{array}{l}\text { Bogdanovichskoe OJSC } \\
\text { "Ogeupory" }\end{array}$ & 0,966 & 1,145 & 1,015 & 1,163 & 0,998 & 0,973 & $-2,387$ & $-2,796$ \\
\hline $\begin{array}{l}\text { JSC Ural Mining } \\
\text { Metallurgical Company }\end{array}$ & 0,751 & 0,828 & 1,097 & 0,900 & 1,183 & 1,112 & $-3,031$ & $-3,399$ \\
\hline OJSC SANDVIK-MKTS & 0,837 & 0,608 & 1,972 & 0,948 & 0,590 & 1,009 & $-2,537$ & $-2,975$ \\
\hline OJSC "Ufaleinickel" & 0,206 & 3,691 & 2,651 & 0,842 & 1,085 & 2,546 & $-1,894$ & $-0,374$ \\
\hline OJSC "Electrozinc" & 1,039 & 3,647 & 1,001 & 1,032 & 1,250 & 0,907 & $-1,140$ & $-0,570$ \\
\hline
\end{tabular}

When using boundary values to identify the degree of distortion in the reporting of American companies, Beneish and Roxas models were more sensitive to the detection of distortions than when using boundary values for the financial statements of Russian companies.

Table 6: Boundary Values of Indicators for Russian and American Models

\begin{tabular}{|l|c|c|}
\hline Beneish and Roxas Boundary values & for American companies & for Russian companies \\
\hline Days' sales in receivables index (DSRI) & 1,031 & 1,408 \\
\hline Gross margin index (GMI) & 1,014 & 1,26 \\
\hline Asset quality index (AQI) & 1,039 & 1,186 \\
\hline Sales growth index (SGI) & 1,134 & 1,28 \\
\hline Depreciation index (DEPI) & - & - \\
\hline
\end{tabular}




\begin{tabular}{|l|c|c|}
\hline $\begin{array}{l}\text { Sales, general, and administrative expenses index } \\
\text { (SGAI) }\end{array}$ & 1 & 1,025 \\
\hline Leverage index (LVGI) & 1 & 1,119 \\
\hline Beneish M-score & $-2,424$ & $-1,802$ \\
\hline Roxas M-score & $-2,965$ & $-2,146$ \\
\hline
\end{tabular}

Table 7 shows that the number of companies with the alleged distortion of financial statements is higher in the American model of calculation than the number in the Russian valuation model.

Table 7: Number of Enterprises with Distorted Financial Indicators

\begin{tabular}{|l|l|l|l|l|l|l|l|l|}
\hline Model type & DSRI & GMI & AQI & SGI & SGAI & LVGI & $\begin{array}{l}\text { Beneish } \\
\text { M-score }\end{array}$ & $\begin{array}{l}\text { Roxas } \\
\text { M-score }\end{array}$ \\
\hline for American companies & 7 & 12 & 9 & 4 & 12 & 7 & 7 & 11 \\
\hline for Russian companies & 3 & 5 & 7 & 2 & 11 & 3 & 2 & 4 \\
\hline
\end{tabular}

It should be noted that using the model based on American practice is not entirely correct. The American model of reporting testing for distortions is not suitable for the assessment of Russian enterprises, as it does not take into account the peculiarities of disclosure of information in accounting (financial) statements.

It means that not all the data necessary for calculating the required indicators present in Russian reports.

\section{Results}

Studies of the frequency of distortions detection in the statements of Russian companies shown in Table 7 demonstrate that the M-score according to the Roxas model is more sensitive to the detection of distortions in both American and Russian models for assessing the degree of reliability of accounting (financial) statements.

Thus, the hypothesis made is not verified: the Beneish test is a less sensitive model in assessing the distortion of information. This gives us reason to assert that the Roxas model is more useful for Russian companies to assess the degree of distortion in the indicators of the financial statements. The adjustments that are associated with the exceptional features of information disclosure in Russian financial statements should be made while using this model.

Based on the conclusions of the research, we will test the degree of distortion in the financial statements of the company under study, LLC "GK Vtormet" belonging to the market of metal collection and processing (Table 8).

Table 8: Express-Test for Detecting Distortions of LLC "GC Vtormet"

\begin{tabular}{|c|c|c|c|c|c|c|c|c|}
\hline \multirow[b]{2}{*}{ Company } & \multicolumn{8}{|c|}{ Indices } \\
\hline & $\begin{array}{l}\vec{n} \\
\tilde{\Omega}\end{array}$ & $\sum_{0}$ & $\underset{\psi}{\sigma}$ & ర্ & 庭 & 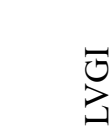 & 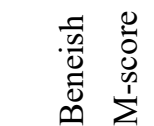 & 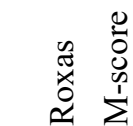 \\
\hline $\begin{array}{l}\text { LLC "GK Vtormet" } \\
(2015-2016)\end{array}$ & 1,433 & 1,061 & 0 & 0,776 & 0,955 & 0,793 & $-2,692$ & $-3,368$ \\
\hline $\begin{array}{l}\text { LLC "GK Vtormet" } \\
(2016-2017)\end{array}$ & 0,28 & 0,812 & 0 & 0,966 & 1,107 & 0,662 & $-3,695$ & $-4,403$ \\
\hline
\end{tabular}

Comparing the indicators with the boundary values in Table 6, we see that the deviation is observed only for the DSRI (2015-2016) and the SGAI (2016-2017).

\section{Conclusion}

The presence of one deviation is not an indicator of the complete distortion of financial statements. Besides, the 
Roxas M-score is within the acceptable marginal norm. The express-test shows that LLC "GK Vtormet" 2015-2017 reporting meets the quality requirements. It means that it is applicable for further use in comprehensive economic analyses of enterprises.

Even though the new valuation models apply to the analysis of Russian enterprises and take into account the particularities of information disclosure in reporting, the analysis methods are imperfect since it is not always possible to identify existing distortions. When comparing reporting testing methods based on the use of American and Russian models, we may see that American models are more sensitive to the detection of distortions.

To improve Russian models, namely to improve the quality of their assessment, to clarify threshold values of the degree of distortion of accounting (financial) statements and to increase the probability of detecting distortions, it is necessary to study not only the financial situation and results of business entities thoroughly and comprehensively but also to evaluate the economic situation at the macroeconomic level, to study the peculiarities of the country's corporate legislation, and the peculiarities of companies' behavior within the industry and the economy as a whole.

\section{Acknowledgements}

This research has been done given the Russian Government Program of Competitive Growth of Kazan Federal University.

\section{References}

[1] Beneish, M.D. (1999). The detection of earnings manipulation. Financial Analysts Journal, 55(5), 24-36.

[2] Beneish, M.D., Marshall, C.D., \& Yang, J. (2017). Explaining CEO retention in misreporting firms. Journal of Financial Economics, 123(3), 512-535

[3] Beneish, M.D., Lee, C.M.C., \& Nichols, D.C. (2013). Earnings manipulation and expected returns. Financial Analysts Journal, 69(2), 57-82

[4] Brazel, J.F., Keith, L.J. Zimbelman M.F. (2009). Using non Financial Measures to assess fraud risk. Journal of Accounting Research, 47( 5), 1135-1166

[5] Kadochnikova, E.I., Semenikhina, N.B., \& Garifullina, A.N. (2019). Econometric assessment of the factors of enterprise receivables. International Journal on Emerging Technologies, 10(2), 75-78

[6] Kulikova, L.I., Vetoshkina, E.Y., \& Nurgatin, R.R. (2016). Universal business activity level highlites in the financial managenet system. Academy of Strategic Management Journal, 15( S1), 114-121

[7] Roxas, Maria L. (2011). Financial Statement Fraud Detection Using Ratio and Digital Analysis. Journal of Leadership, Accountability and Ethics, 8(4)

[8] Shtefan, M.A., \& Feruleva, N.V. (2017). Audit of falsification of financial statements: Specific aspects. National Research University Higher School of Economics, City of Nizhny Novgorod, 20(2), 88-105

[9] Shtefan, M.A., \& Feruleva, N.V. (2016). Identifiying facts of financial statements in Russian companies: analysis of applicability of Beneish and Roxas models. NRU Higher School of Economics - Nizhny Novgorod, 14(3), 49-70

[10] Tukhvatullin, R.S., \& Pratchenko, O.V. (2014) Budgeting system in construction organizations in conditions of process-oriented normative model of cost accounting. Mediterranean Journal of Social Sciences, 5(24), 56-60 [11] Vetoshkina, E.Yu., Salcina, Yu.A., \& Cherepanova, P.S. (2018). Detection of financial stataments fraud in an audit of the Beneish and Roxas models applicability. Kazan (Volga Region) Federal University, Kazan Economic Newsletter, 1, 82-88. 